\title{
A biochemical study of hydroxyapatite crystal induced enzyme release from neutrophils
}

\author{
JAN G R ELFERINK AND MARTHA DEIERKAUF
}

From the Department of Medical Biochemistry, Sylvius Laboratories, University of Leiden, PO Box 9503, $\overrightarrow{0}$ 2300 RA Leiden. The Netherlands

SUMMARY Addition of hydroxyapatite (HyAp) microcrystals to human neutrophils results in exocytosis of specific granules, measured as lysozyme release, and plasma membrane damage, evident from lactate dehydrogenase $(\mathrm{LDH})$ release. The strong hydrogen acceptoris polyvinylpyridine- $N$-oxide has no effect on enzyme release, but polyanions and negatively $\mathscr{E}$ charged proteins such as albumin strongly inhibit HyAp induced enzyme release. HyAp crystals 을 cause only slightly less membrane damage in neutrophil cytoplasts than in intact neutrophils. $\vec{T}$ Removal of sialic acid from the cells did not affect HyAp induced enzyme release. Glucose, trapped in negatively charged liposomes, is released by HyAp crystals, whereas the crystals do $\frac{-}{\omega}$ not release glucose from positively charged liposomes. The results indicate that positive charges located on the HyAp crystals are of predominant importance for the effect of the crystals, and $\underset{\cup}{\infty}$ that the lipid part of the membrane might play an important part in the interaction.

Key words: positive charges.

Microcrystals of hydroxyapatite (HyAp) have been observed in association with a number of pathogenic conditions. HyAp crystals have been found in patients with several types of arthritis, such as osteoarthritis, bursitis, periarthritis, erosive arthritis, and in the Milwaukee shoulder syndrome. ${ }^{1-10}$ When HyAp crystals are injected in vivo at appropriate places a severe inflammation results. ${ }^{11} 12$

The precise mechanisms by which HyAp crystals cause inflammation are largely unknown. In recent years, however, a number of studies have been performed to clarify this. HyAp crystals are able to interact with several cell types, eventually resulting in the release of inflammation promoting constituents. ${ }^{12-15}$

Neutrophils are associated with a wide range of inflammatory conditions, owing to their ability to release tissue degrading enzymes and to produce toxic oxygen metabolites upon activation. ${ }^{16-18}$ Intrapleural injection of HyAp in the rat causes an inflammatory reaction consisting of exudate and a mixed leucocyte population of neutrophils and mononuclear cells. ${ }^{19}$

Accepted for publication 25 February 1987.

Correspondence to Dr Jan G R Elferink. Department of Medical Biochemistry. Sylvius Laboratories. University of Leiden. PO Box 95(13. 2300 RA Leiden. The Netherlands.
The ability of the neutrophil to release tissued degrading enzymes and inflammation promoting constituents upon activation, and the presence of that cell type in the vicinity of HyAp depositions suggests that the neutrophil may serve as a possible mediator in HyAp crystal associated inflammations.

For this reason a biochemical study was under $-\frac{\pi}{0}$ taken to observe the interaction between HyApo microcrystals and neutrophils and thus determine the ability of the crystals to release cellular constituents from neutrophils and make an approach towards establishing the mechanism of this release.o

We stated in a preliminary report that $\mathrm{HyAp}_{\triangle}$ crystals may cause cell damage in erythrocytes and? rabbit peritoneal neutrophils, that phagocytosis may be involved in crystal induced cell damage in rabbio neutrophils, and that positive charges might play is part in cell-crystal interaction. ${ }^{1+}$ Using human neut ${ }_{\mathrm{E}}$ rophils we have elaborated the experimental basis of these statements in an attempt to localise the targeto of HyAp crystals in the cell.

\section{Materials and methods}

N E U T R O P H ILS

Human neutrophils were isolated from heparinised? blood by dextran sedimentation, followed by lysis of the remaining erythrocytes and separation of the 
white blood cells by the Ficoll-Isopaque technique, according to the method described by Böyum. ${ }^{20}$ The medium used consisted of $140 \mathrm{mM} \mathrm{NaCl}, 5 \mathrm{mM}$ $\mathrm{KCl}, 10 \mathrm{mM}$ glucose, and $20 \mathrm{mM}$ HEPES $(N-2-$ hydroxyethylpiperazine- $N^{\prime}$-2-ethanesulphonic acid) $\mathrm{pH} 7 \cdot 3$. Before the experiment $1 \mathrm{mM} \mathrm{Ca}^{++}$and $1 \mathrm{mM} \mathrm{Mg}^{++}$were added to the medium. Neutrophils $\left(3 \times 10^{6} / \mathrm{ml}\right)$ were incubated for $30 \mathrm{~min}$ at $37^{\circ} \mathrm{C}$. Then $100 \mu \mathrm{l} 0 \cdot 1 \mathrm{M}$ EDTA (ethylenediaminetetra-acetic acid) was added to dissolve the crystals, and the suspension was centrifuged and the supernatant analysed.

\section{HY DROXYA PATITE CRYSTALS}

Microcrystals of hydroxyapatite were prepared according to the method of Hayek and Newesely. ${ }^{21}$ $\mathrm{Ca}\left(\mathrm{NO}_{3}\right)_{2} \cdot 4 \mathrm{H}_{2} \mathrm{O}(7.9 \mathrm{~g})$ was dissolved in water, alkalinised with ammonia to $\mathrm{pH} 12$, and brought to a volume of $60 \mathrm{ml}$. $\left(\mathrm{NH}_{4}\right)_{2} \mathrm{HPO}_{4}(2 \cdot 7 \mathrm{~g})$ was dissolved in water, alkalinised to $\mathrm{pH} 12$, and brought to a volume of $80 \mathrm{ml}$. Under vigorous stirring the latter solution was added to the $\mathrm{Ca}\left(\mathrm{NO}_{3}\right)_{2}$ solution. The precipitate was washed several times until ammonia free and then suspended in medium. The suspension was sonified briefly ( $20 \mathrm{~s})$ and diluted to a stock suspension of $10 \mathrm{mg}$ hydroxyapatite/ml. This method of preparation yields very small crystals of length $50-200 \mathrm{~nm}$ as determined by electron microscopy. The strong adsorption of proteins, such as $\mathrm{LDH}$, to HyAp was overcome by dissolving the crystals after the experiment in $0.01 \mathrm{M}$ EDTA. The final concentration of HyAp during the experiments was $100 \mu \mathrm{g} / \mathrm{ml}$, unless otherwise indicated.

\section{ENZYME RELEASE}

Release of the cytoplasmic enzyme lactate dehydrogenase $(\mathrm{LDH})$ was determined as a measure of plasma membrane damage (cytolysis). The release of granule associated enzymes, lysozyme and $\beta$ glucuronidase, was measured to establish a possible involvement of granule exocytosis in the enzyme release process. $\mathrm{LDH}$ was assayed by measuring the conversion of $\mathrm{NADH}$ into $\mathrm{NAD}^{+}$(nicotinamide adenine dinucleotide) during the reaction of pyruvate to lactate. Lysozyme release was assayed by measuring the rate of lysis of Micrococcus lysodeikticus at $\mathrm{pH} 6 \cdot 2$, according to the method of Shugar. ${ }^{22}$ $\beta$-Glucuronidase was assayed by measuring the release of nitrophenol from $p$-nitrophenyl- $\beta$-Dglucuronide, as previously described. ${ }^{23}$ Enzyme release is expressed as a percentage of maximal enzyme release after disruption of the cells with $0 \cdot 2 \%$ Triton $\mathrm{X}-100$.

NEURAMINIDASE TREATMENT

Neutrophils, $10^{\times}$in $2 \mathrm{ml}$ buffer $\mathrm{pH} 6 \cdot 5$, were incubated with 10 units neuraminidase (Sigma Chemical Co, St Louis, MO, type V) for $30 \mathrm{~min}$ at $37^{\circ} \mathrm{C}$. Then the cells were centrifuged; in the supernatant the liberated sialic acid was estimated according to Warren. ${ }^{24}$ The cells were washed with medium and resuspended. Control cells were treated in the same way but without neuraminidase.

\section{I POS OMES}

Multilamellar liposomes were prepared from 100 $\mu \mathrm{mol}$ purified egg yolk lecithin. $75 \mu \mathrm{mol}$ cholesterol, and $10 \mu \mathrm{mol}$ of a charged lipid (dicethyl phosphate for negatively charged liposomes and stearylamine for positively charged liposomes). The lipids were dissolved in chloroform and spread as a thin film on the surface of a flask by rotary evaporation of the solvent in vacuo at $40^{\circ} \mathrm{C}$. Subsequently, $5 \mathrm{ml}$ of $0.3 \mathrm{M}$ glucose solution was added, the mixture was left at $40^{\circ} \mathrm{C}$ for $30 \mathrm{~min}$, and then the lipids were dispersed by vortexing for two minutes. The liposome suspension was dialysed extensively against $0.15 \mathrm{M} \mathrm{NaCl}$. In the experiments $500 \mu \mathrm{l}$ liposome suspension was mixed with HyAp or $0 \cdot 15$ $\mathrm{M} \mathrm{NaCl}$, brought to $1 \mathrm{mM} \mathrm{Ca}^{++}$and $1 \mathrm{mM} \mathrm{Mg}^{++}$, and incubated in a final volume of $0.7 \mathrm{ml}$ for one hour at $37^{\circ} \mathrm{C}$. Then the reaction mixture was placed in a dialysis bag and dialysed against $1.5 \mathrm{ml} 0.15 \mathrm{M}$ $\mathrm{NaCl}$ for one hour. In the latter solution glucose was determined according to Bergmeyer et al. ${ }^{25}$ The glucose measured in the control experiment (liposomes without crystals added) and which represents residual glucose, and glucose release in the absence of crystals, is subtracted from the glucose release. The release of glucose in excess of control is expressed as a percentage of glucose released from liposomes treated with $0 \cdot 2 \%$ Triton X-100.

\section{CYTOPLASTS}

Cytoplasts were prepared from neutrophils according to Roos et al, ${ }^{26}$ using discontinuous gradients of Ficoll containing cytochalasin B. Control neutrophils were treated with cytochalasin $B$, and the same washing proccdure was followed to avoid differences as a consequence of residual cytochala$\sin \mathrm{B}$.

\section{CHEMICALS}

Polyvinylpyridine- $N$-oxide was obtained from $\mathrm{K}$ and $\mathrm{K} / \mathrm{ICN}$ Pharmaceuticals (Plainview, NY). The following chemicals were from Sigma Chemical Co: poly-D-glutamic acid, mol. wt 66000 ; poly-Lglutamic acid, mol. wt 95000 ; heparin, 140 USP (United States pharmacopaeia) units/mg; dextran sulphate, mol. wt 500 000; rabbit albumin catalase and neuraminidase, type $\mathrm{V}$ from Clostridium perfringens. Pentex rabbit serum was from Miles 


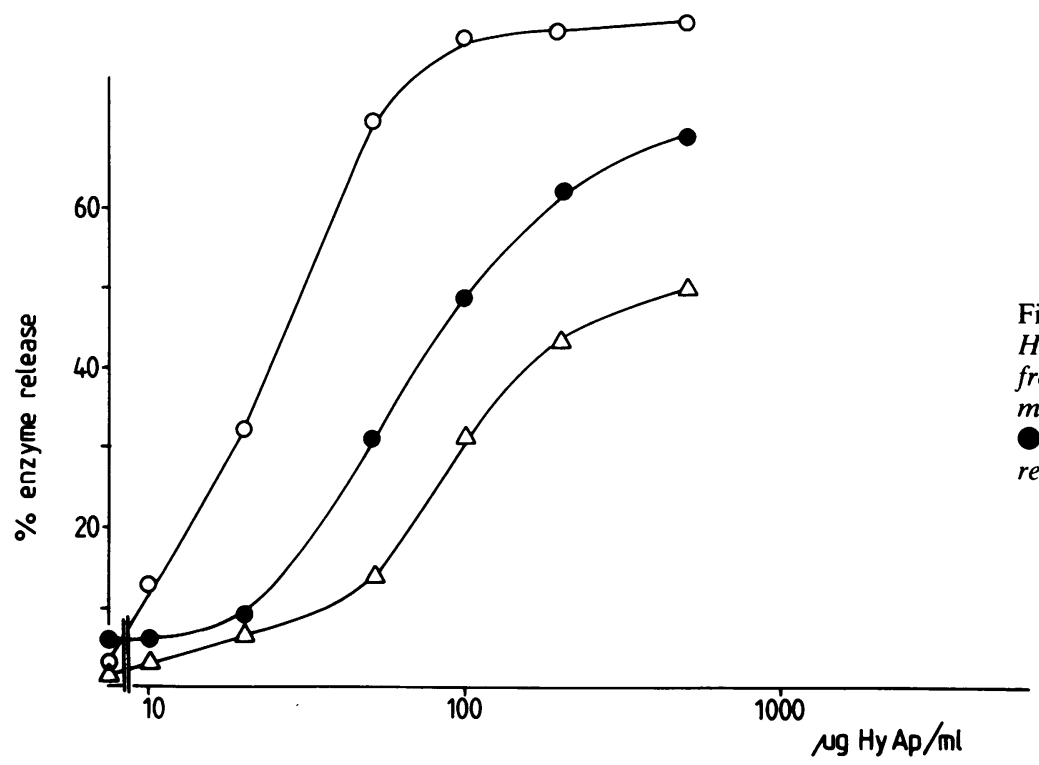

Fig. 1 Concentration dependence of HyAp crystal induced enzyme release from neutrophils. Values given are the mean value of three experiments.

$-L D H$ release $;=$ lysozyme release; $\triangle=$ glucuronidase release.

Laboratories (Elkhart, IN). Cytochalasin A and cytochalasin B were from Aldrich Chemical Co (Milwaukee, WI). Egg yolk lecithin, cholesterol, dicethyl phosphate, and stearylamine were from Sigma Chemical Co; the lecithin was purified before use.

\section{Results}

Hydroxyapatite crystals caused a dose and time dependent release of enzymes from human neut- rophils (Figs 1 and 2). This release referred both tôم cytoplasmic products such as lactate dehydrogenase $\mathrm{V}$ (LDH), and to granule associated enzymes such as lysozyme and glucuronidase. The percentage of lysozyme release was considerably higher than tha? of LDH release, whereas the percentage of glucur onidase release was less. The release of $L D H \mathbb{B}$ followed a sigmoid curve both in the time and the concentration curve.

Release of enzymes occurred in the absence of

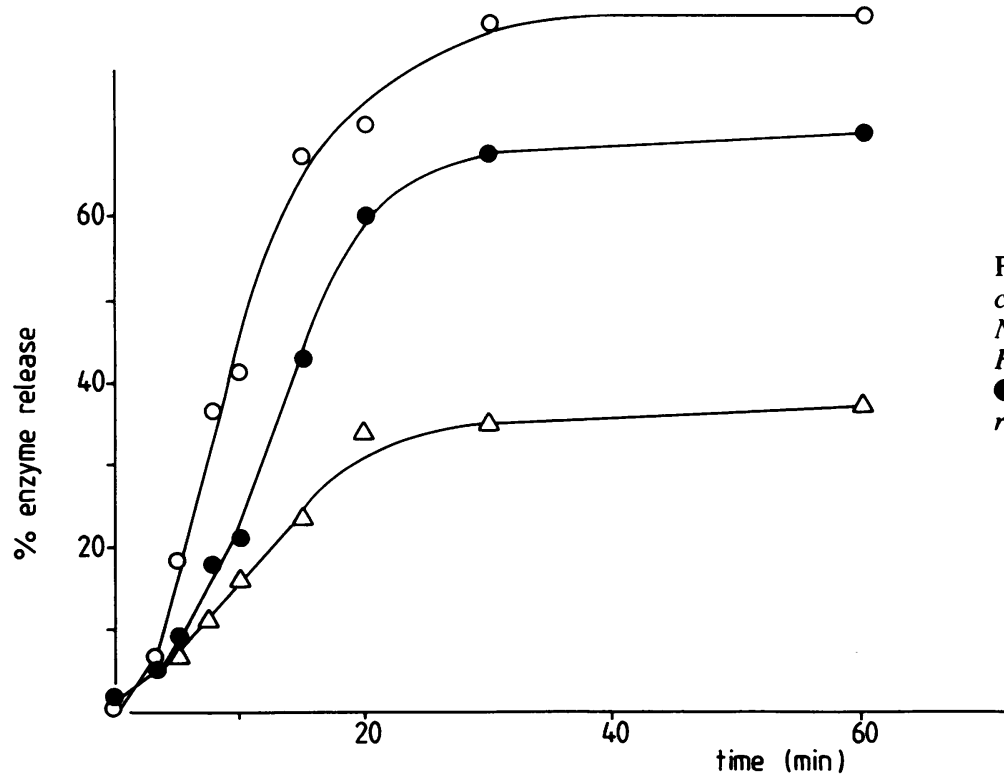

Fig. 2 Time dependence of $\mathrm{HyAp}$ crystal induced enzyme release. Neutrophils were exposed to $100 \mu \mathrm{g}$ $\mathrm{HyAp/ml} \mathrm{for} \mathrm{a} \mathrm{given} \mathrm{time} \mathrm{at} 37^{\circ} \mathrm{C}$. $O=L D H$ release $; O=$ lysozyme release; $\Delta=$ glucuronidase release. 


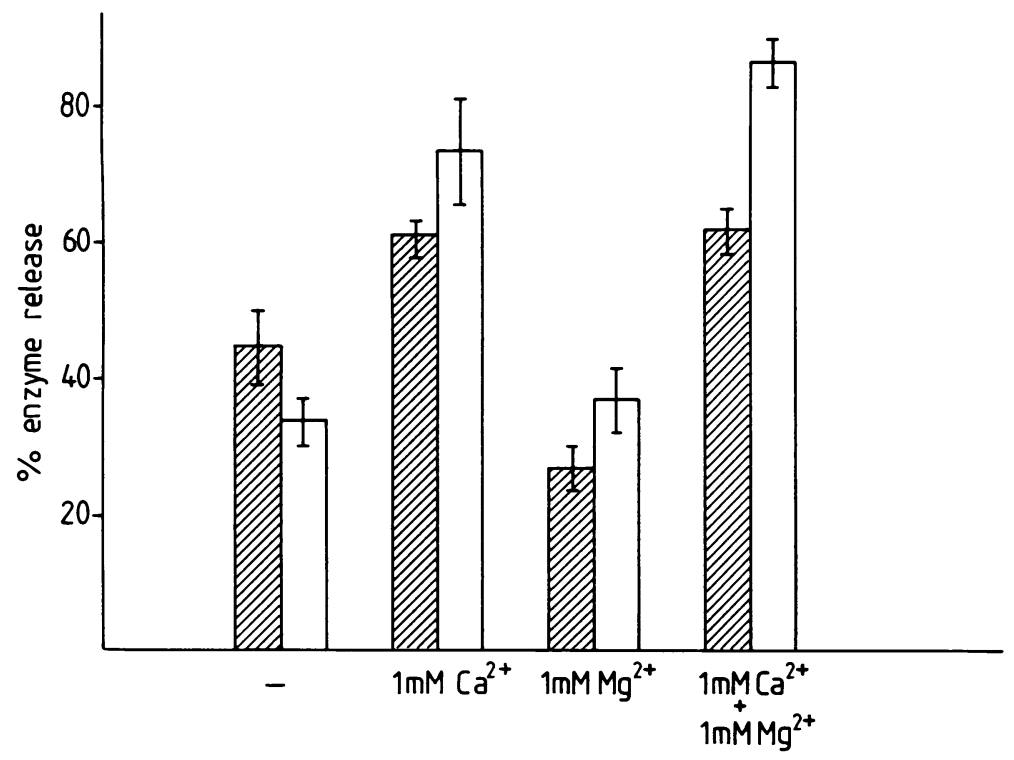

Fig. 3 Effect of divalent cations on HyAp induced enzyme release. Neutrophils were exposed to $100 \mu \mathrm{g}$ $\mathrm{HyAp/ml}$ in the presence of the indicated cations for $30 \mathrm{~min}$ at $37^{\circ} \mathrm{C}$. The values given are the mean value of three experiments $(S D) . \mathbb{Z}=L D H$ release; $\square=$ lysozyme release. divalent cations, but the presence of $\mathrm{Ca}^{++}$had a strong potentiating effect, especially on lysozyme release (Fig. 3). A number of agents were tested that are known to interfere with the different cellular targets involved in phagocytosis and exocytosis. All these agents inhibited HyAp induced enzyme release (Table 1). The inhibition, however, was not complete, and for most agents was less than the degree of inhibition reported in published work for phagocytosis or exocytosis.

As previously shown with rabbit peritoneal granulocytes the strong hydrogen acceptor polyvinylpyridine- $N$-oxide has no influence on the

Table 1 Inhibition of HyAp-neutrophil interaction by several agents

\begin{tabular}{|c|c|c|}
\hline \multirow[t]{2}{*}{ Inhibitor } & \multicolumn{2}{|c|}{ Enzyme release (\%) } \\
\hline & $L D H$ & Lysozyme \\
\hline - & $62(3)^{*}$ & $87(3)$ \\
\hline Cytochalasin A $(5 \mu \mathrm{mol} / \mathrm{l})$ & $36(4)$ & $42(4)$ \\
\hline Cytochalasin B $(5 \mu \mathrm{mol} / \mathrm{l})$ & $36(3)$ & $85(3)$ \\
\hline p-Bromophenacyl bromide $(10 \mu \mathrm{mol} / \mathrm{l})$ & $20(4)$ & $26(7)$ \\
\hline$N$-Ethylmaleimide $(100 \mu \mathrm{mol} / \mathrm{l})$ & $37(3)$ & $21(4)$ \\
\hline Iodoacetate $(0.5 \mathrm{mmol} / \mathrm{l})$ & $45(3)$ & $47(6)$ \\
\hline $\mathrm{Zn}^{++}(1 \mathrm{mmol} / \mathrm{l})$ & $16(4)$ & $11(3)$ \\
\hline $\mathrm{Co}^{++}(1 \mathrm{mmol} / \mathrm{l})$ & $23(4)$ & $54(2)$ \\
\hline 2-Deoxyglucose $(20 \mathrm{mmol} / \mathrm{l})$ & $55(2)$ & $81(6)$ \\
\hline
\end{tabular}

Cells were preincubated with the given concentration of inhibitor for $10 \mathrm{~min}$ at $37^{\circ} \mathrm{C}$. Then $100 \mu \mathrm{g}$ HyAp was added and the solution incubated for $30 \mathrm{~min}$ at $37^{\circ} \mathrm{C}$.

*Values given are the mean of three experiments (SD). interaction between crystals and neutrophils. Several negatively charged polymers, such as polyglutamic acid, dextran sulphate, and heparin, strongly diminished HyAp induced enzyme release from neutrophils (Fig. 4). This applied both to LDH and lysozyme release. The same occurred with negatively charged proteins: albumin (and thus serum too) and catalase strongly inhibited HyAp induced enzyme release (Table 2); release of LDH was more strongly inhibited than release of lysozyme.

Because the preceding experiments suggested a role for positive charges in the cell-crystal interaction an attempt was made to localise these positive charges. Neutrophils or HyAp crystals were pretreated with the polyanion poly-D-glutamic acid, followed by centrifugation and washing to remove loosely bound polyanion. The pretreated cells or crystals were then exposed to non-treated crystals or cells respectively, and the degree of inhibition by the adherent polyanion was compared with the results of an experiment in which the polyanion was added before the incubation of cells with crystals (Table 3 ). The interaction between pretreated neutrophils and HyAp gave about the same enzyme release as that of control cells with HyAp. The interaction between cells and pretreated HyAp, however, gave almost no enzyme release and resembled the situation in which the polyanion was present during incubation.

Treatment of neutrophils with neuraminidase to remove the negatively charged sialic acid residues from the cell surface had little or no effect on the subsequent interaction between cell and HyAp 


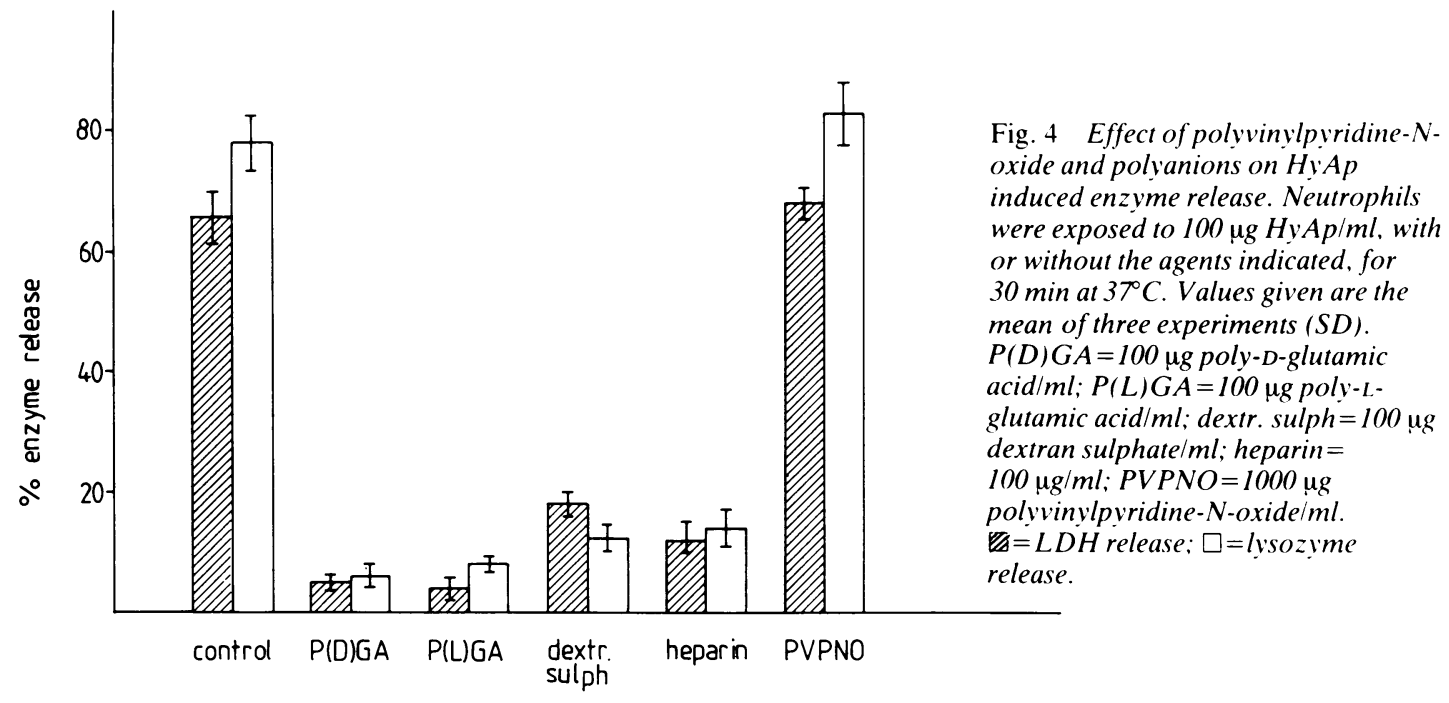

crystals: the enzyme release for neuraminidase treated cells was only slightly different from that of control cells (Fig. 5).

HyAp crystals were able to release glucose trapped in multilamellar liposomes (Fig. 6). This release occurred only when the liposomes were negatively charged: with positively charged liposomes the release of glucose in the presence of crystals was even less than control. The polyanion poly-D-glutamic acid completely annihilated the effect of HyAp on negatively charged liposomes (Table 4). With positively charged liposomes the polyanion gives a higher glucose release than with crystals alone. probably as a consequence of the interaction of negatively charged polyanion with the positively charged liposomes.

Table 2 Effect of some proteins on HyAp crystal induced enzyme release

\begin{tabular}{|c|c|c|}
\hline \multirow[t]{2}{*}{ Protein } & \multicolumn{2}{|c|}{ Enzyme release $(\%)$} \\
\hline & $L D H$ & Lysozyme \\
\hline- & $64(2)^{*}$ & $8.3(5)$ \\
\hline Serum $(50 \mu \mathrm{g})$ & $14(3)$ & $63(4)$ \\
\hline Scrum $(500) \mu \mathrm{g})$ & $6(3)$ & $23(5)$ \\
\hline Albumin $(50 \mu \mathrm{g})$ & $15(1)$ & $49(7)$ \\
\hline Albumin $(500 \mu \mathrm{g})$ & $3(1)$ & $14(4)$ \\
\hline Catalase $(50 \mu \mathrm{g})$ & $66(3)$ & $77(5)$ \\
\hline Catalase $(500 \mu \mathrm{g})$ & $21(4)$ & $68(5)$ \\
\hline Superoxide dismutase $(50 \mu \mathrm{g})$ & $67(2)$ & $87(6)$ \\
\hline Superoxide dismutase $(500 \mu \mathrm{g})$ & $66(1)$ & $78(4)$ \\
\hline
\end{tabular}

Neutrophils were incubated with $100 \mu \mathrm{g} \mathrm{HyAp} / \mathrm{ml}$, with or without the proteins as indicated for $30 \mathrm{~min}$ at $37^{\circ} \mathrm{C}$.

${ }^{*}$ Values given are the mean of three experiments (SD).
Treatment of cytoplasts, prepared from neut $\overrightarrow{\overrightarrow{0}}$ rophils, with HyAp crystals showed that LDHo0 release was only slightly less than that of control cells. Some lysozyme release could be measured

Table 3 Effect of pretreatment of cells or cristals with poly-D-glutamic acid on $H_{y} A p$ induced enzyme release $\frac{D}{8}$

\begin{tabular}{|c|c|c|c|}
\hline & \multicolumn{2}{|c|}{ Enzlme release $(\%)$} & \multirow[b]{2}{*}{ Glucuronidase' } \\
\hline & $L D H$ & Lysozyme & \\
\hline Cclls + HyAp & $62(4)$ & $85(6)$ & $44(3)$ \\
\hline \multicolumn{4}{|l|}{ Cells + PGA +} \\
\hline HỵAp & $6(1)$ & $10(2)$ & $+(2)$ \\
\hline \multicolumn{4}{|c|}{ Cells (control)+ } \\
\hline Hỹp & $54(3)$ & $66(3)$ & $35(2)$ \\
\hline \multicolumn{4}{|l|}{ Cells $(\mathrm{PG} A)+$} \\
\hline HyAp & $50(2)$ & $64(4)$ & $37(2)$ \\
\hline \multicolumn{4}{|l|}{ Cells + HyAp } \\
\hline (control) & $49(5)$ & $63(6)$ & $41(3)$ \\
\hline \multicolumn{4}{|l|}{ Cells+HyAp } \\
\hline$(P G A)$ & $5(1)$ & $6(2)$ & $3(1)$ \\
\hline
\end{tabular}

HyAp $=l(K) \mu \mathrm{g}$ hydroxyapatitc/ml: PGA $=l(K) \mu \mathrm{g}$ poly-1)-glutami尺 acid $(\mathrm{mol}$ wt $66(k()))$ per $3 \times 10^{\prime \prime}$ cells or per $1(k) \mu \mathrm{g}$ HyAp. Cells (PGA): $3 \times 10^{6}$ neutrophils were pretreated with $1(x)$ ug P(; for $10 \mathrm{~min}$ at $37^{\circ} \mathrm{C}$ : then the cells were eentrifuged. washed. and resuspended. Cells (control) underwent the same treatment buf without PGA

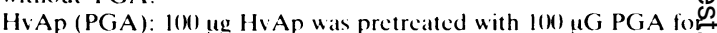
10 min at $37^{\circ} \mathrm{C}$ : then the ervstals were eentrifuged. washed, and resuspended. HyAp (control) underwent the same treatment bub without PGA.

Cells and crystals, with or without pretreatment as indicated. wer@ mixed and incubated for $30 \mathrm{~min}$ at $37^{\circ} \mathrm{C}$ : then EDTA was added the suspension was centrifuged. and the supernatant analysed. values given are the mean of three experiments (SD). 


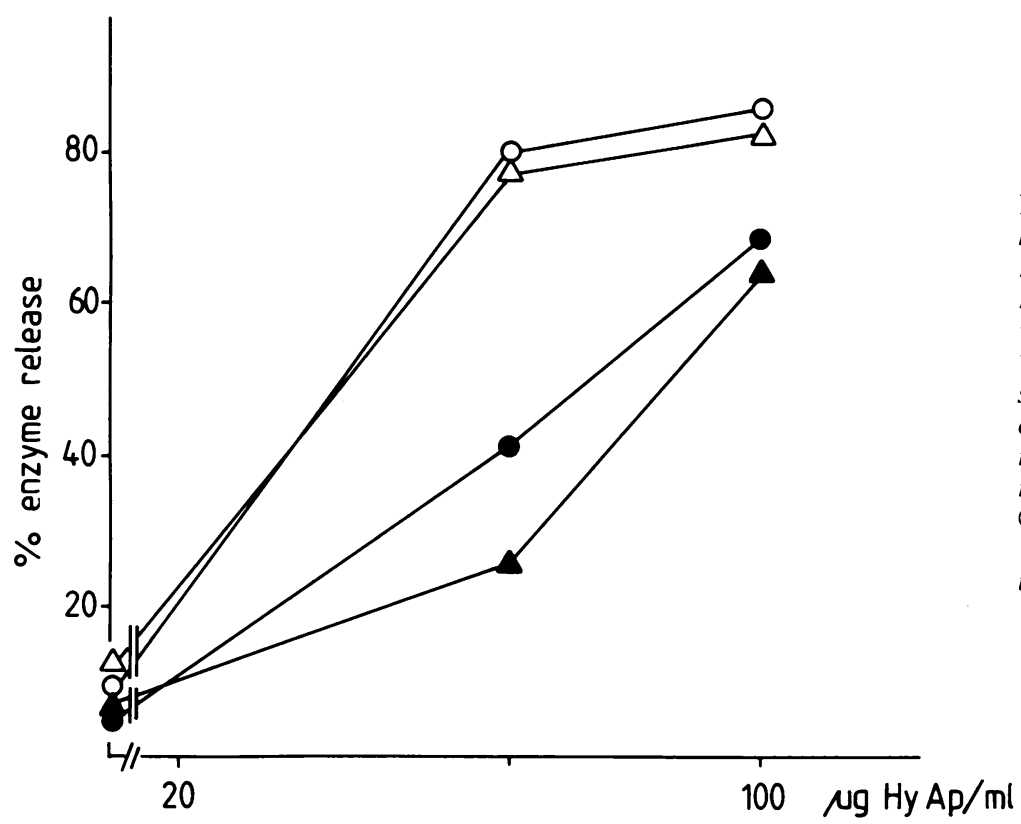

Fig. 5 Effect of pretreatment of neutrophils with neuraminidase on HyAp crystal induced enzyme release. Neutrophils were treated with or without neuraminidase as described in 'Materials and methods' and subsequently exposed to different concentrations of $\mathrm{HyAp} . \mathrm{ODH}$ release, control cells; $\Delta=L D H$ release, neuraminidase treated cells; $\mathrm{O}=$ lysozyme release, control cells; $\triangle=$ lysozyme release, neuraminidase treated cells.

but the amount was very low, indicating that the cytoplast has lost the major part of the granules, in accordance with data of other publications. ${ }^{26}$ The membrane damaging effect of the crystals on cytoplasts could be antagonised by poly-D-glutamic acid (Table 5).

\section{Discussion}

The study of HyAp crystal induced enzyme release from cells is hampered by the fact that HyAp has a high and specific affinity for certain proteins, including LDH, the release of which we used as a measure for plasma membrane damage. This difficulty was solved by dissolving the crystals with EDTA at the end of the experiment. Owing to the small size, the crystals were rapidly dissolved, and this procedure facilitated the subsequent experimental procedure.

HyAp crystals appear to have two different effects on neutrophils: $(a)$ a membrane damaging effect. as can be deduced from the leakage of the cytoplasmic enzyme LDH; $(b)$ an activating effect, resulting in

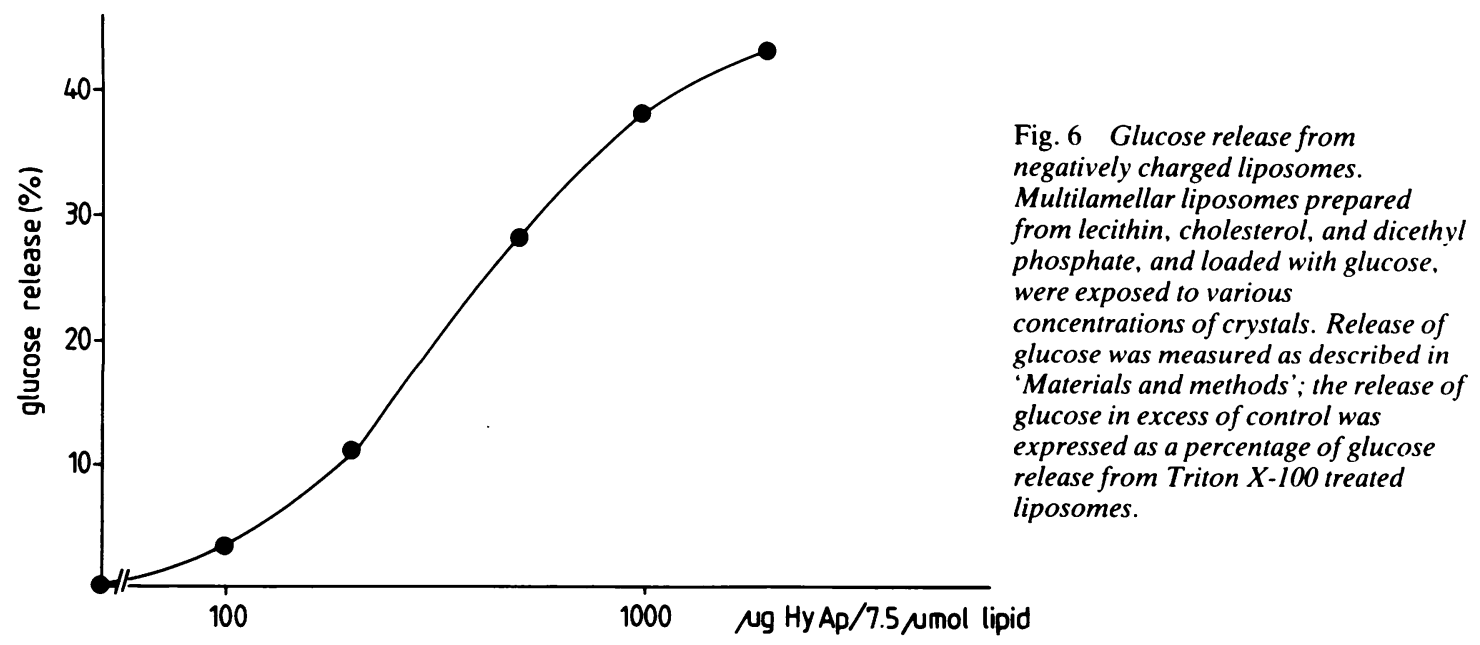

Fig. 6 Glucose release from negatively charged liposomes. Multilamellar liposomes prepared from lecithin, cholesterol, and dicethyl phosphate, and loaded with glucose, were exposed to various concentrations of crystals. Release of glucose was measured as described in 'Materials and methods'; the release of glucose in excess of control was release from Triton $X-100$ treated liposomes. 
Table 4 Hydroxyapatite crystal induced glucose release from liposomes

Glucose release $(\%)^{\dagger}$

\begin{tabular}{lr}
\hline Negative liposomes, HyAp & $51(3)^{*}$ \\
Negative liposomes. HyAp, PGA & $0(3)$ \\
Positive liposomes, HyAp & $-9(2)$ \\
Positive liposomes, HyAp, PGA & $9(1)$ \\
\hline
\end{tabular}

HyAp $=2000 \mu \mathrm{g}$ hydroxyapatite; $\mathrm{PGA}=1000 \mu \mathrm{g}$ poly-D-glutamic acid.

*Values given are the mean of four experiments (SD).

tGlucose release in excess of control is expressed as a percentage of maximal glucose release obtained by treatment with Triton $\mathrm{X}-100$.

exocytosis. Release of lysozyme is greater than that of $\mathrm{LDH}$, which indicates that membrane damage is preceded by exocytosis of specific granules. The release of glucuronidase does not allow conclusions about a possible exocytosis of azurophilic granules. Because glucuronidase release is less than LDH release this can either indicate exocytosis of azurophilic granules, or cell disintegration which follows plasma membrane damage. The release of cellular constituents, either due to plasma membrane damage or exocytosis, results in the liberation of a large number of inflammation promoting constituents, and may thus lead to inflammation.

It has been shown previously that HyAp crystals are phagocytised by neutrophils. ${ }^{15}$ Phagocytosis is often accompanied by exocytosis, and this may explain the activating effect of the crystals. Cytochalasin B, which inhibits phagocytosis but not exocytosis, inhibits mainly LDH release but not lysozyme release from neutrophils. Inhibitors of phagocytosis and exocytosis, interfering with different targets such as metabolism (deoxyglucose, iodoacetate),

Table 5 Hydroxyapatite crystal induced enzyme release from neutrophil cytoplasts

\begin{tabular}{|c|c|c|c|}
\hline & \multicolumn{3}{|c|}{ Enzyme release $(\%)$ from: } \\
\hline & \multicolumn{2}{|c|}{ Control cells } & \multirow{2}{*}{$\frac{\text { Cytoplasts }}{L D H}$} \\
\hline & $L D H$ & Lysozyme & \\
\hline - & $7(2)$ & $14(3)$ & $10(2)$ \\
\hline $1(x) \mu g$ НyAp & $73(4)$ & $80(5)$ & $60(4)$ \\
\hline $\begin{array}{r}1(0) \mu \mathrm{g} \text { HyAp } \\
100 \mu \mathrm{g} \text { PGA }\end{array}$ & $5(4)$ & $11(4)$ & $8(2)$ \\
\hline
\end{tabular}

Control cells were treated with the same concentration of cytochalasin B as cytoplasts, and received the same washing procedure.

PGA = poly-D-glutamic acid, mol. wt 66000 .

*Values given are the mean of three experiments (SD). sulphydryl groups (cytochalasin A, ethylmaleimide), 은 phospholipase $\mathrm{A}_{2}$ (bromophenacyl bromide), and unknown targets $\left(\mathrm{Co}^{++}, \mathrm{Zn}^{++}\right)$, have modulating $\stackrel{+}{+}$ effects on HyAp induced enzyme release. It seems을 likely, therefore, that phagocytosis plays a part in흐 the enzyme releasing effect of the crystals. This also $\frac{\bar{\sigma}}{7}$ explains the potentiating effect of $\mathrm{Ca}^{++}$because this $\stackrel{\odot}{\circledR}$ ion is known to promote phagocytosis. The picture is incomplete, however, because enzyme release is usually not completely inhibited by these agents, which are known to block phagocytosis (and exocyto- $\vec{\omega}$ sis) completely. ${ }^{27-29}$ This may be related to the small size of the crystals which enables them to be phagocytised without opsonisation.

In contrast with the action of urate crystals and $\frac{\hat{\sigma}}{\infty}$ silica, ${ }^{31-32}$ hydrogen bonding interactions do not in appear to play an important part in HyAp induced $\mathscr{\Xi}^{\circ}$ enzyme release, as is indicated by the lack of effect 을 of polyvinylpyridine- $N$-oxide. Polyanions strongly inhibit HyAp induced enzyme release, which points to an important role for positive charges in the을 interaction. Cells and crystals have both positive and $\stackrel{\oplus}{\oplus}$ negative charges on their surface and the net overall $\vec{\bullet}$ charge is dependent on the $\mathrm{pH}$, but even when the overall charge is negative the positive charges may play an important part in certain interactions. The experiment in which cells or crystals were pretreated with polyanion indicates that the polyanion has a $\bar{O}$ high affinity for HyAp crystals and that the bound $\stackrel{\square}{\varnothing}$ polyanion blocked the subsequent interaction with $\odot$ cells. It seems likely, therefore, that the positive $\overrightarrow{\overrightarrow{0}}$ charges which are playing a predominant part in the 3 cell-crystal interaction are located on the crystal surface.

This mechanism may have important consequences for the effect of HyAp in vivo. As shown by our in vitro experiments, some negatively charged 3 proteins have a strong inhibiting effect on the cellcrystal interaction. A comparable modulating effect by negatively charged proteins may be exerted in vivo in places where HyAp crystals are deposited, and induce inflammation.

Sialic acid residues make an important contribution to the negative charge on the cell surface. $N$ Removal of these sialic acid residues with neurami- $N$ nidase has little effect on the cell-crystal interaction. ㅇ It seems therefore unlikely that an interaction $\omega$ between the positive charges on the crystals and the negatively charged sialic acid residues play an important part in the cell-HyAp interaction.

The experiments with liposomes show that $\mathrm{HyAp} ?$ crystals are able to disrupt lipid bilayer membrane when these are negatively charged. Polyanions $\vec{\oplus}$ annihilate the disrupting effect. These results indi- $\frac{?}{\Phi}$ cate that here too positive charges on the crystals $\stackrel{\mathbb{Q}}{\circ}$ play a predominant part and that the lipid section of 
the membrane may be the target of the HyAp crystals.

For the disruption of phagocytes by urate crystals a mechanism has been proposed in which the crystals exert their effect after phagocytosis by an attack on the phagolysosome membrane. ${ }^{31}{ }^{32}$ The results with cytoplasts show that the membranes of these neutrophil derived structures can be damaged by HyAp without the involvement of granules; in this regard they resemble human erythrocytes, which are readily haemolysed by HyAp crystals. ${ }^{33}$ Phagocytosis nevertheless appears to have a role in HyAp induced enzyme release as can be deduced from the effect of cytochalasin $\mathrm{B}, \mathrm{Ca}^{++}$, and inhibitors, but the nature of this role is not easy to establish. It may be that phagocytosis results in the formation of a protein free region in the membrane, thus allowing an easier attack by other crystals on these lipid regions. Such a mechanism does not exclude an attack of the crystals taken up by phagocytosis on the phagolysosome membrane. The relative contribution of these processes to the final release of enzymes remains to be established.

We want to thank Dr D Roos and coworkers for their advice in preparing cytoplasts.

\section{References}

1 Schumacher H R. Smolyo A P. Tse R L. Maurer K. Arthritis associated with apatite crystals. Ann Intern Med 1977; 87: 411-16.

2 Halverson P B. McCarthy D J. Identification of hydroxyapatite crystals in synovial fluid. Arthritis Rheum 1979; 22: 389-95.

3 Schumacher H R, Gibilisco P. Reginato A. Cherian V. Gordon G. Implications of crystal deposition in osteoarthritis. $J$ Rheumatol 1983: 10: 40-1.

4 Pinals R S. Short C L. Calcific periarthritis involving multiple sites. Arthritis Rheum 1964: 7: 359-67.

5 Fam A G. Pritzker K P H. Stein J L. Houpt J B. Little A H. Apatite associated arthropathy: a clinical study of 14 cases and of 2 paticnts with calcific bursitis. J Rheumatol 1979; 6: 461-71.

6 Bonavita J A. Dalinska M K. Schumacher H R. Hydroxyapatite deposition discase. Radiology 1980; 134: 621-5.

7 Schumacher H R. Miller J L. Ludovico C. Jessar R A. Erosive arthritis associated with apatite crystal deposition. Arthritis Rheum 1981; 24: 31-7.

8 Hakim F T, Cranley R, Brown K S, Eanes E D, Harne L, Oppenheim J J. Hereditary joint disorder in progressive ankylosis (ank/ank) mice. 1. Association of calcium hydroxyapatite deposition with inflammatory arthropathy. Arthritis Rheum 1984; 27: 1411-20.

9 Halverson P B. Cheung H S, Carrura G F, Kozin F, Garancis J. McCarty D J. Rotator cuff tcars associated with synovial fluid hydroxyapatite crystals and activated collagenase. Arthritis Rheum 1980; 23: 687-94.

10 Garancis J C. Cheung H S. Halverson P B. McCarty D J. 'Milwaukec shoulder': association of microspheroids containing hydroxyapatite. active collagenase and neutral protease with rotator cuff defects. Arthritis Rheum 1981: 24: 484-91.

11 Denko C W. Whitehouse M W. Experimental inflammation induced by naturally occurring microcrystalline calcium salts $J$ Rheumatol 1976: 3: 54-62.

12 Denko C W. Petricevic M. Hydroxyapatite crystal-induced inflammation and prostaglandin E1. J Rheumatol 1979: 6: 117-23.

13 Cheung H S. Halverson P B. McCarty D J. Release of collagenase. neutral protease and prostaglandins from cultured mammalian synovial cells by hydroxyapatite and calcium pyrophosphate dihydrate crystals. Arthritis Rheum 1981: 24: $1338-44$.

14 Elferink J G R. Riemersma J C. Hydroxyapatite crystalinduced membrane damage in granulocytes and erythrocytes. Agents Actions 1983: 13: 515-6.

15 Maurer K H, Schumacher H R. Hydroxyapatite phagocytosis by human polymorphonuclear leukocytes. Ann Rheum Dis 1979; 38: 84-8.

16 Weissmann G. Smolen J E. Korchak H M. Release of inflammatory mediators from stimulated neutrophils. $N$ Engl $J$ Med 1980; 303: 27-34.

17 Fantone J C. Ward P A. Role of oxygen-derived free radicals and metabolites in leukocyte dependent inflammatory reactions. Am J Pathol 1982: 107: 397-418.

18 Barret A J. The possible role of neutrophil proteinases in damage to articular cartilage. Agents Actions 1978; 8: 11-18.

19 Dieppe P A. Crocker P. Huskesson E C. Willoughby D A Apatite deposition disease-a new arthropathy. Lancet 1976: i: $266-9$.

20 Böyum A. Isolation of lymphocytes. granulocytes and macrophages. Scand J Immunol 1976: 5: 9-15.

21 Hayek E. Newesely H. Pentacalcium mono-hydroxyorthophosphate (hydroxyapatite). Inorg Synth 1963: 7: 63-5.

22 Shugar D. The measurement of lysozyme activity and the ultraviolet inactivation of lysozyme. Biochim Biophys Acta 1952: 8: 302-9.

23 Elferink J G R. Chlorpromazine inhibits phagocytosis and exocytosis in rabbit polymorphonuclear leukocytes. Biochem Pharmacol 1979; 28: 965-8.

24 Warren $\mathrm{L}$. The thiobarbituric assay of sialic acids. J Biol Chem 1959; 234: 1971-5.

25 Bergmeyer H U. Bernt E. Schmidt F. Stork H. D-Glucose. Determination with hexokinase and glucose-6-phosphate dehydrogenase. In: Bergmeyer $\mathrm{H}$ U et al. Methods of enzymatic analysis. Weinheim: Verlag Chemie, 1974; 3: 1196-201.

26 Roos D. Voetman A A. Meerhof L J. Functional activity of cnucleated human polymorphonuclear leukocytes. J Cell Biol 1983; 97: 368-77.

27 Smolen J E, Weissmann G. Effects of indomethacin, 5, 8, 11, 14-eicosatetranoic acid and p-bromophenacylbromide on lysosomal enzyme release and superoxide anion generation by human polymorphonuclear leukocytes. Biochem Pharmacol 1980; 29: 533-8.

28 Elferink J G R, Riemersma J C. Effects of sulfhydryl reagents on phagocytosis and exocytosis in rabbit polymorphonuclear leukocytes. Chem Biol Interact 1980; 30: 139-49.

29 Silverstein S C, Steinman R M, Cohn Z A. Endocytosis. Ann Rev Biochem 1977; 46: 669-722.

30 Allison A C, Harington J S, Birbeck M. An examination of the cytotoxic effects of silica on macrophages. $J$ Exp Med 1966; 124: 141-54.

31 Hoffstein S, Weissmann G. Mechanisms of lysosomal enzyme release from leukocytes IV. Interaction of monosodium urate crystals with dog fish and human leukocytes. Arthritis Rheum 1975; 18: 153-65.

32 Rich A M, Giedd K N, Cristello P, Weissmann G. Granules are necessary for death of neutrophils after phagocytosis of crystalline monosodium urate. Inflammation 1985; 9: 221-32.

33 Elferink J G R. Crystal-induced membrane damage: hydroxyapatite crystal-induced hemolysis of erythrocytes. Biochem Med Metabol Biol 1986: 36: 25-35. 